\title{
Ecology of phlebotomine sand flies in a Brazilian area with recent leishmaniasis transmission (Itaúna, in Minas Gerais state)
}

\author{
Nathália Cristina Lima Pereira ${ }^{[1]}$, Érika Monteiro Michalsky ${ }^{[1]}$, Fabiana Oliveira Lara-Silva ${ }^{[1]}$, \\ Rosana Silva Lana ${ }^{[1]}$, Adão Júnior Viana de Paula ${ }^{[1]}$, Daniele Marques Pereira ${ }^{[1]}$, \\ Josiane Valadão Lopes ${ }^{[1]}$, Consuelo Latorre Fortes-Dias ${ }^{[2]}$ and Edelberto Santos Dias ${ }^{[1]}$
}

[1]. Instituto René Rachou, Fundação Oswaldo Cruz, Belo Horizonte, MG, Brasil.

[2]. Fundação Ezequiel Dias, Belo Horizonte, MG, Brasil.

\begin{abstract}
Introduction: Leishmaniasis constitutes a serious but neglected tropical disease. Recently, socio-environmental, biological and physical changes have altered the range of leishmaniasis, causing it to spread into urban areas. In Minas Gerais, the disease is endemic, exhibiting regional differences and reaching urban centers. The purpose of this study was to evaluate entomological aspects related to the ecoepidemiology of leishmaniasis in Itaúna. Methods: Monthly catches with HP traps were carried out from June 2017 to May 2018, in three ecological areas (urban, rural, and forest). The adaptability of the species to anthropic environments was assessed using the synanthropy index (SI). Results: We collected 1306 specimens of phlebotomine sand flies. Of the species of medical importance, Lutzomyia longipalpis, the vector of Leishmania infantum, represented $90.4 \%$ of the specimens identified at species level ( $\mathrm{n}=1260)$. Nyssomyia whitmani, the vector of Leishmania braziliensis, represented 1.6\% of the total. Lu. longipalpis displayed an SI of +95.8, a value that denotes a marked preference for human environments. For $N y$. whitmani, the SI was -25 , expressing the tendency of this species to occupy uninhabited areas. The population of the three most numerous species captured increased with rain, high temperatures, and high relative humidity. Although captured at low numbers, $N y$. whitmani showed a different profile concerning the climate variables analyzed. Conclusions: Understanding the epidemiology of the disease may assist the health services in formulating effective control measures for improving community health and contributing to the establishment of a dynamic relationship and a global awareness of the health/disease process.
\end{abstract}

Keywords: Leishmaniasis. Phlebotominae. Synanthropy index. Lutzomyia longipalpis. Nyssomyia whitmani.

\section{INTRODUCTION}

Leishmaniases are anthropozoonotic infectious diseases transmitted by the bite of Leishmania-infected female phlebotomine sand flies. In the American continent, their two basic forms are visceral leishmaniasis (VL) and cutaneous leishmaniasis (CL)1. Previously, leishmaniases were associated with rural and nonanthropic areas, where human beings could accidentally get infected by passing through or colonizing infected $\operatorname{areas}^{2}$. Over the years, this pattern has changed, and currently the transmission cycle also occurs in urban centers ${ }^{3}$.

\footnotetext{
Corresponding author: Edelberto Santos Dias.

e-mail: edelberto.dias@fiocruz.br

(D) 0000-0002-2370-5113

Received 21 November 2019

Accepted 13 February 2020
}

Epidemiological studies have shown that changes in the transmission profile and increasing urbanization of leishmaniases can be due to deforestation and the haphazard growth of cities, which reduces and modifies the natural habitats of these insects, restricting their environment and causing species adaptation ${ }^{4,5}$. Nuorteva ${ }^{6}$ named the ability of certain species to adjust to humancreated or modified environmental conditions, which generally result from urbanization, synanthropy. The synanthropy index (SI) measures the degree of adaptability of species to urbanized environments and has been studied from an ecological perspective to evaluate the results of human influence on the original fauna of an environment.

Studies have shown that climatic factors, such as temperature, rainfall and relative humidity can also correlate with the occurrence of phlebotomine sand flies and their population density ${ }^{7}$. An understanding of the ecology of Leishmania vectors and their monthly distribution associated with these climate variables 
can contribute to a better comprehension of the epidemiology of leishmaniases and their dynamics and possibly improve the effectiveness of control strategies in transmission areas ${ }^{8}$.

The Ministry of Health (MS) has recently classified Itaúna (Minas Gerais) as an area of sporadic transmission of VL. The municipality is concerned because of the increased number of human and canine cases, the presence of the competent vector ( $L u$. longipalpis) and Itaúna's proximity to endemic areas. Thus, in order to elucidate the ecology of the phlebotomine sand flies in relation to the epidemiology of leishmaniasis, we started a project in the municipality of Itaúna. This involved a survey of the sand fly fauna, calculation of the synanthropic index of each species captured and evaluation of the influence of climate on the population density of these insects. These data may contribute to the establishment of a dynamic relationship and a global understanding of the health/ disease process, leading to more effective and integrated measures for efficient disease control in Itaúna.

\section{METHODS}

\section{Study Area}

This study was conducted in Itaúna $\left(20^{\circ} 4^{\prime} 26^{\prime \prime} \mathrm{S}, 44^{\circ} 34^{\prime} 24^{\prime \prime} \mathrm{W}\right)$, a municipality in the state of Minas Gerais, Brazil. Itaúna is located in the midwestern region of the state, $76 \mathrm{~km}$ from Belo Horizonte. According to the Brazilian Institute of Geography and Statistics ${ }^{9}$ the municipality comprises an area of $495,769 \mathrm{~km}^{2}$, with approximately 72 neighborhoods and an estimated population of 92,561 inhabitants. The region is hilly with a clayey soil and a tropical climate with hot summers and dry winters. Average altitude is $893 \mathrm{~m}$ with minimum of $711 \mathrm{~m}$ and maximum of $1321 \mathrm{~m}$. Itauna's biome is cerrado and Atlantic Forest ${ }^{9}$.

\section{Capture and Identification of Phlebotomine Sand Flies}

The entomological captures were made in three ecologically distinct areas: urban, rural, and forest. The favorable criteria considered for the selection of capture points were the presence of fruit trees, abundant vegetation, accumulation of organic matter in the soil, and presence of chicken-coops and domestic animals. Thus, the urban site selected for this study was a residence located in a neighborhood called "Chácara do Quitão" $\left(20^{\circ} 05^{\prime} 32^{\prime \prime} \mathrm{S}\right.$, $44^{\circ} 35^{\prime} 55^{\prime \prime} \mathrm{W}$, altitude $864 \mathrm{~m}$ ), which is predominantly residential and has a dense human occupation, located near the city center, with the presence of chickens, pigs and dogs. The rural area selected for this study was a farm in Piaguassu neighborhood $\left(20^{\circ} 03^{\prime} 26^{\prime \prime} \mathrm{S}\right.$, $44^{\circ} 36^{\prime} 55^{\prime \prime} \mathrm{W}$, altitude $818 \mathrm{~m}$ ), with few dwellings and the presence of pasture, gardens, chickens, pigs, cattle, goats, dogs, and cats. The selected forest area belongs to the Zoonoses Control Center (ZCC), located in the Industrial District $\left(20^{\circ} 02^{\prime} 26^{\prime \prime} \mathrm{S}, 44^{\circ} 36^{\prime} 54^{\prime \prime} \mathrm{W}\right.$, altitude $844 \mathrm{~m}$ ), at a distance of $10 \mathrm{~km}$ from the urban center of Itaúna, which has a vast area of transitional forest (cerrado and semi-deciduous seasonal forest) with wild birds and mammals, a small perennial stream, and low solar incidence. In the forest area, the ZCC was taken as reference for placement of the traps. To minimize any possible bias due to sporadic and intermittent presence of horses and dogs in ZCC facility, the traps were mounted at about $300 \mathrm{~m}$ from the facility.
The captures were performed monthly, during three consecutive nights, from June 2017 to May 2018, using three HP light traps ${ }^{10}$ for each ecological area. In each area, the traps were placed at $300 \mathrm{~m}$ from each other. The male specimens were stored in $70 \%$ alcohol for subsequent taxonomic identification, and the females were conditioned in $6 \% \mathrm{DMSO}$ and stored at $-20^{\circ} \mathrm{C}$ for further dissection (taxonomic identification). Identification at species level was performed according to the classification proposed by Galati ${ }^{11}$ with abbreviation of the generic names as proposed by Marcondes ${ }^{12}$.

\section{Climate data}

Monthly climate data, including temperature $\left({ }^{\circ} \mathrm{C}\right)$, relative humidity $(\%)$, wind speed $(\mathrm{m} / \mathrm{s})$, and rainfall $\left(\mathrm{mm}^{3}\right)$, were obtained from the nearest weather station in the municipality (OMM83635), District of the Brazilian Institute of Meteorology of Divinópolis, through the National Institute of Meteorology ${ }^{13}$. Divinópolis is located approximately $43 \mathrm{~km}$ from Itaúna $\left(20^{\circ} 8^{\prime} 21^{\prime \prime} \mathrm{S} 44^{\circ} 53^{\prime} 17^{\prime \prime} \mathrm{W}\right)$.

\section{Synanthropy index}

The synanthropy index (SI) was calculated according to Nuorteva formula ${ }^{6}$. The index ranges from +100 (maximum) to -100 (minimum), with positive values representing the highest degree of association with man and negative values indicating aversion to the urban environment.

$$
\mathrm{SI}=\frac{2 a+b-2 c}{2}
$$

where

$a=$ percentage of a species captured in urban areas

$b=$ percentage of the same species captured in rural areas

$c=$ percentage of the same species captured in forest areas

\section{RESULTS}

During the 12 months of the study period, 1306 phlebotomine sand flies were captured, among which 1260 were identified at level species. The sand flies captured belonged to six genera (Lutzomyia, Evandromyia, Pintomyia, Nyssomyia, Psathyromyia and Brumptomyia), and included 11 species: Brumptomyia brumpti (Larrousse, 1920), Evandromyia cortelezzii (Brèthes, 1923), Evandromyia evandroi (Costa Lima \& Antunes, 1936), Evandromyia lenti (Mangabeira, 1938), Evandromyia sallesi (Galvão \& Coutinho, 1940), Evandromyia termitophila (Martins, Falcão \& Silva, 1964), Lu. longipalpis (Lutz \& Neiva, 1912), Nyssomyia whitmani (Antunes \& Coutinho, 1939), Pintomyia pessoai (Coutinho \& Barreto, 1940), Psathyromyia brasiliensis (Costa Lima, 1932), and Psathyromyia lutziana (Costa Lima, 1932) (Table 1). Among them, 1099 were males (87.5\%) and 161 females $(12.5 \%)$, with an $\mathrm{M} / \mathrm{F}$ ratio of 7.0 . Thirty-eight females were identified as belonging to the cortelezzii complex because female specimens of Ev. cortellezzii and Ev. sallesi are indistinguishable. Forty-six specimens were considered unidentified (3.5\%) because the morphological characters necessary for their identification at 
TABLE 1: Distribution of male and female of phlebotomine sand fly species $(n=1260)$ captured in Itaúna, Minas Gerais state, Brazil. June 2017 to May 2018.

\begin{tabular}{|c|c|c|c|c|c|c|c|c|c|c|c|c|c|}
\hline \multirow{2}{*}{ Species } & \multicolumn{3}{|c|}{ Urban area } & \multicolumn{3}{|c|}{ Rural area } & \multicolumn{3}{|c|}{ Forest area } & \multicolumn{4}{|c|}{ Total } \\
\hline & $\hat{o}$ & 우 & $\begin{array}{c}\text { Both } \\
\text { genders }\end{array}$ & 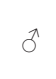 & 우 & Both genders & 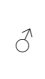 & 우 & Both genders & $\sigma^{\lambda}$ & 우 & $\begin{array}{l}\text { Both } \\
\text { genders }\end{array}$ & $\%$ \\
\hline Br. brumpti & 1 & 2 & 3 & - & 1 & 1 & - & 1 & 1 & 1 & 4 & 5 & 0.40 \\
\hline cortelezzii complex & - & 28 & 28 & - & 6 & 6 & - & 4 & 4 & - & 38 & 38 & 3.02 \\
\hline Ev. cortelezzii & 5 & - & 5 & - & - & - & - & - & - & 5 & - & 5 & 0.40 \\
\hline Ev. evandroi & 5 & 5 & 10 & - & - & - & - & - & - & 5 & 5 & 10 & 0.79 \\
\hline Ev. lenti & 8 & 13 & 21 & - & 5 & - & - & 1 & 1 & 8 & 19 & 27 & 2.14 \\
\hline Ev. sallesi & 1 & - & 1 & - & - & - & - & - & - & 1 & - & 1 & 0.08 \\
\hline Ev. termitophila & - & 1 & 1 & - & 1 & 1 & 1 & - & 1 & 1 & 2 & 3 & 0.24 \\
\hline Lu. longipalpis & 977 & 73 & 1050 & 84 & 3 & 87 & 1 & 1 & 2 & 1062 & 77 & 1139 & 90.40 \\
\hline Ny. whitmani & 2 & 1 & 3 & 3 & 3 & 6 & 6 & 5 & 11 & 11 & 9 & 20 & 1.59 \\
\hline Pi. pessoai & - & - & - & 3 & - & 3 & 1 & 4 & 5 & 4 & 4 & 8 & 0.63 \\
\hline Pa. brasiliensis & - & - & - & - & - & - & - & 1 & 1 & - & 1 & 1 & 0.08 \\
\hline Pa. lutziana & 1 & - & - & - & - & - & - & 2 & 2 & 1 & 2 & 3 & 0.24 \\
\hline Total & 1000 & 123 & 1023 & 90 & 19 & 109 & 9 & 19 & 28 & 1099 & 161 & 1260 & 100.00 \\
\hline
\end{tabular}

species level were missing. The main species of medical importance were $\mathrm{Lu}$. longipalpis (VL vector), which represented $90.4 \%$ of the specimens captured, and $\mathrm{Ny}$. whitmani (CL vector), $1.6 \%$.

During the period studied, monthly rainfall ranged from 0 $\mathrm{mm}$ to $332.5 \mathrm{~mm}$. The average temperature and relative humidity were 21.9 (standard deviation [SD] $2.6^{\circ} \mathrm{C}$ and 64.3 (SD 11.3\%), respectively. The dry season extended from Apr. to Sept. and the rainy season from Oct. to Mar. The overall profile of the three main climate variables was similar to that of the previous two years (Figure 1). The population curve of the predominant species in our study (Lu. longipalpis) is shown in Figure 2. A populational peak was observed in the warm and rainy season, when relative humidity increases. Although captured at much smaller numbers compared to Lu. longipalpis (Table 1), population curves were also constructed for the cortelezzii complex, Ev. lenti, and $N y$. whitmani. Whereas populations of the first two species oscillated in a similar way to Lu. longipalpis, $N y$. whitmani showed a populational peak in the dry season.

Throughout the study period, 1123 (89.1\%) specimens were captured in the urban area, $109(9.7 \%)$ in the rural area, and 28 (2.2\%) in the forest. Ev. cortelezzii, Ev. evandroi and Ev. sallesi were caught only in the urban area, and $P a$. brasiliensis only in the forest. The other species were found in at least two of the three ecological areas, in various proportions. Regarding species richness, nine species were captured in the urban area, six species in the rural area and eight species in the forest. These results are represented by a logic diagram (Figure 3). A greater number of males was captured in urban and rural areas, while a higher number of females was captured in the forest, all of them identified at species level (Table 1).
Regarding the synanthropy index, Ev. evandroi showed absolute synanthropy (SI +100$)$ and $P a$. brasiliensis showed absolute asynanthropy (SI -100). Ev. lenti and Lu. longipalpis showed a high degree of adaptability to the urban environment, with SI +83.4 and SI +95.8, respectively (Table 2). Considering that the cortelezzii complex included only females and that Ev. cortelezzi and $E v$. salles $i$ were only represented by male specimens, it was not possible to calculate their synanthropy index.

\section{DISCUSSION}

The geographical distribution of leishmaniases in the country indicates that its epidemiology is influenced by a great range of environmental, climatic and socioeconomic aspects ${ }^{7}$,14-16. Moreover, the emergence of new risk factors has favored human-vector contact, leading to new epidemiological scenarios and increasing the incidence of leishmaniases. These new epidemiological scenarios might demand improvements in the control program ${ }^{17-19}$.

Over recent years, Minas Gerais has experienced a significant increase in the number of reported cases of VL, representing $71 \%$ of the total cases recorded in the southeast of Brazil ${ }^{20}$. During our study in the municipality of Itaúna in Minas Gerais state, 1306 specimens were captured, with a fauna of 11 species, distributed in six genera (Table 1). Among the species, we highlight the presence of Lu. longipalpis and $N y$. whitmani, which are acknowledged vectors of Le. infantum and Le. braziliensis. These results are similar to those found in another study conducted in the municipality, where the same genera and almost all the same species were captured $^{21}$.

As climatic factors may influence the population dynamics of phlebotomine sand flies, it is fundamentally important to understand 


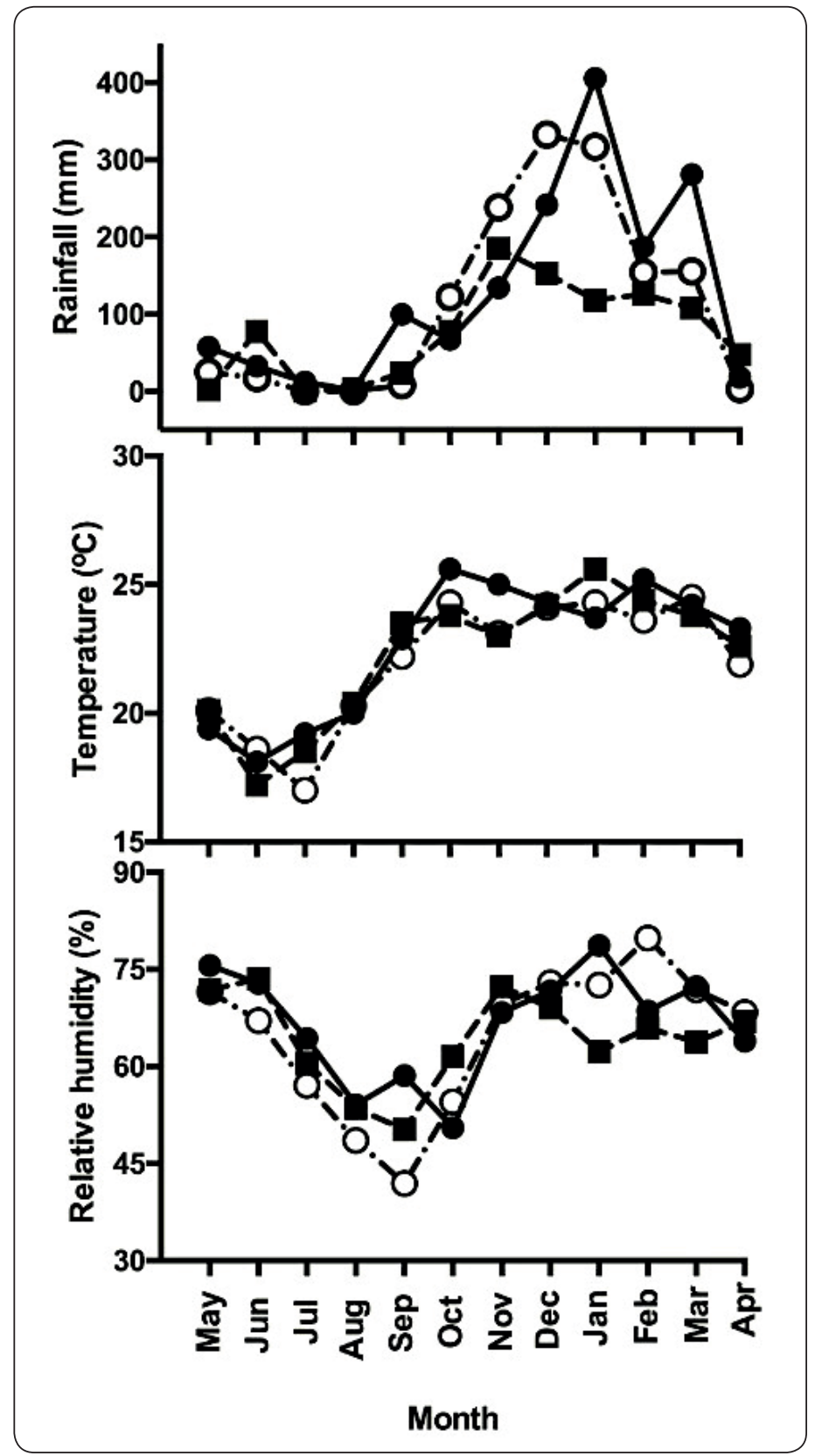

FIGURE 1: Historical series of main climate variables (rainfall, temperature and relative humidity) in Itaúna, Minas Gerais state, Brazil. Legend: black circle 2015/2016, black square 2016/2017; white circle - 2017/2018 (present study).

the seasonal distribution of these insects for the implementation of effective vector control programs ${ }^{22}$. Climate variables have a definite impact on phlebotomine populations, depending on the region. By analyzing the relationship between climate data and population fluctuation in $\mathrm{Lu}$. longipalpis, our results demonstrate peaks of capture in warm and wet months (with higher relative humidity and rainfall) in Itaúna (Figure 2). Other studies performed in Brazil also found peaks of Lu. longipalpis during hot and rainy months ${ }^{21,23,24,26-29}$. The distinct profile found for $N y$. whitmani may be regarded with caution due to the small number of specimens (20 specimens) captured in our study (Figure 2).
TABLE 2: Synanthropy index (SI) for phlebotomine sand fly species captured in three areas (forest, rural and urban) of Itaúna, Minas Gerais state, Brazil, from June 2017 to May 2018.

\begin{tabular}{cc}
\hline Species & SI \\
\hline Br. brumpti & +50.0 \\
Ev. evandroi & +100.0 \\
Ev. lenti & +83.4 \\
Ev. termitophila & +16.6 \\
Lu. longipalpis & +95.8 \\
Ny. whitmani & -25.0 \\
Pi. pessoai & +95.8 \\
Pa. brasiliensis & -100.0 \\
Pa. lutziana & -33.4 \\
\hline
\end{tabular}

The occurrence of a particular sand fly species in a given ecological area (urban, rural or forest) is related to its adaptation to environmental conditions, resource availabilities and its competitive interaction with other species ${ }^{30}$. In the present study, the richness and abundance of species varied between the localities, confirming that environmental or geographical factors may determine a different configuration of phlebotomine sand fly populations. When analyzing the density of sand fly species in each ecological area, it was observed that the smallest number of specimens captured occurred in the forest area (2.1\%) (Figure 3). Studies carried out in forest environments showed a phlebotomine fauna generally composed of a few dominant species and many species with few specimens, corroborating our findings ${ }^{31,32}$. In contrast, the largest number of captured specimens was found in the urban area (89.3\%) (Figure 2), and this may be due to the presence of kennels, chicken-coops and fruit trees, which present ideal characteristics for the proliferation of sand flies ${ }^{33,34}$. Some authors highlight the relevance of animal shelters as places for establishment and maintenance of a high sand fly density in the environment and consider these places as risk factors ${ }^{11,35,36}$. However, the rural area also presents such characteristics and a considerably smaller number of specimens was captured here when compared to the urban area $(8.58 \%)$. This fact indicates the importance of studying the fauna of different ecological areas and the behavior of each species captured.

In the present study, a high density of the predominant species (Lu. longipalpis) was found in the urban environment (92.2\%) with SI +95.8 (Table 2). The abundance and frequency of this species in the urban area of Itaúna resemble those recorded by several other studies in Brazil ${ }^{37-41}$, including a recent entomological fauna survey developed by our group in Itaúna ${ }^{21}$. According to $\mathrm{Melo}^{42}$, among all sand fly species, the most adapted to the anthropic environment is Lu. longipalpis. Its high degree of adaptation to the peridomestic environment of anthropic areas is mainly influenced by the presence of domestic animals ${ }^{21,24,25,26,27,40,43}$. In the forest area, ZCC was taken as reference for the placement of traps. The low number of Lu. longipalpis captured in the area (two specimens only) indicated that the distance between the traps and ZCC was adequate. The sporadic presence of horses and dogs in the ZCC did not bias the results. 

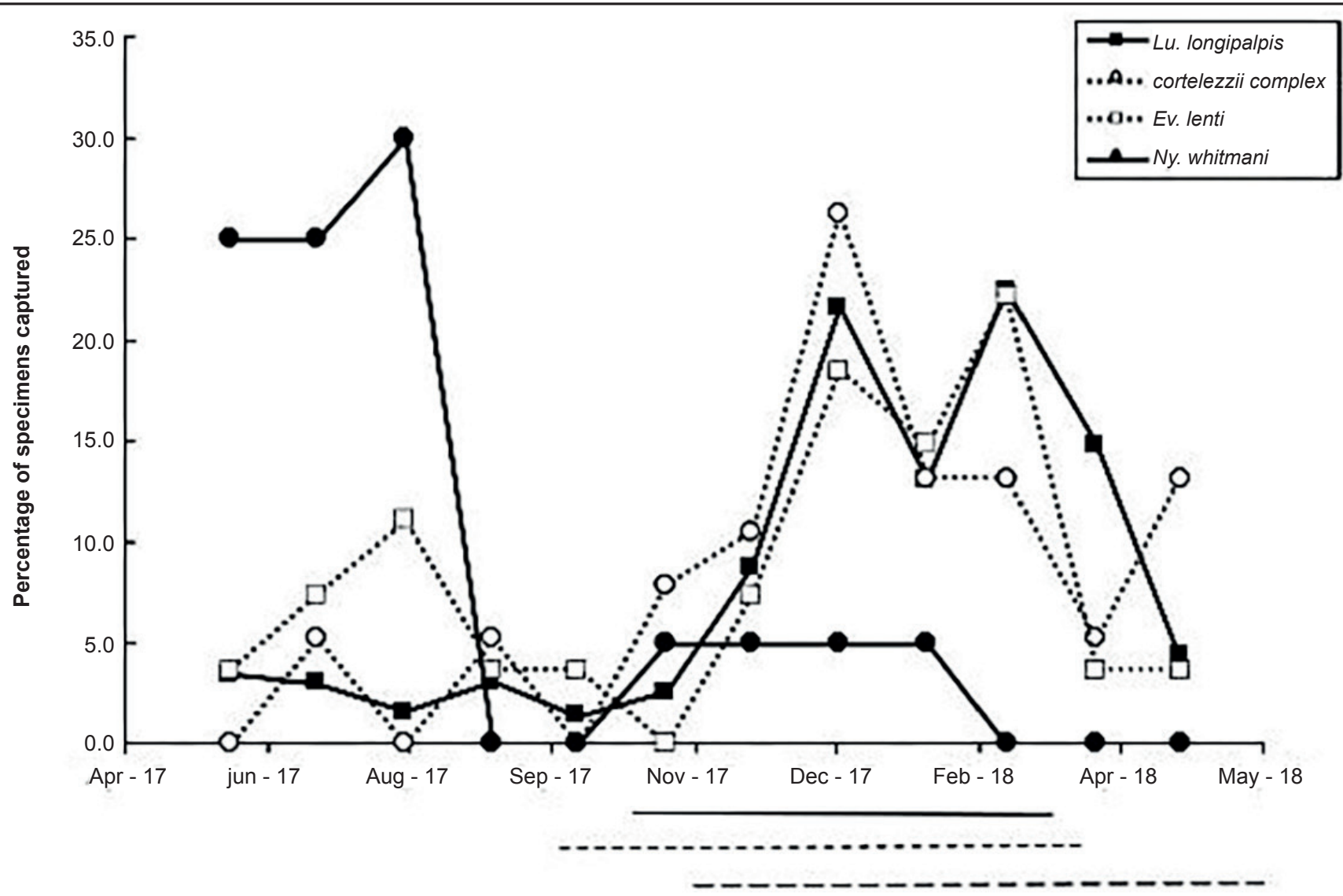

Month and year

FIGURE 2: Population curves of the four most numerous species of phlebotomine sand flies captured in Itaúna, Minas Gerais state, Brazil. Months with climate variables above the averages in the studied period are marked by lines below the abscissa: rainfall - continuous line; temperature - short dashed line; relative humidity- long dashed line. June 2017 to May 2018.

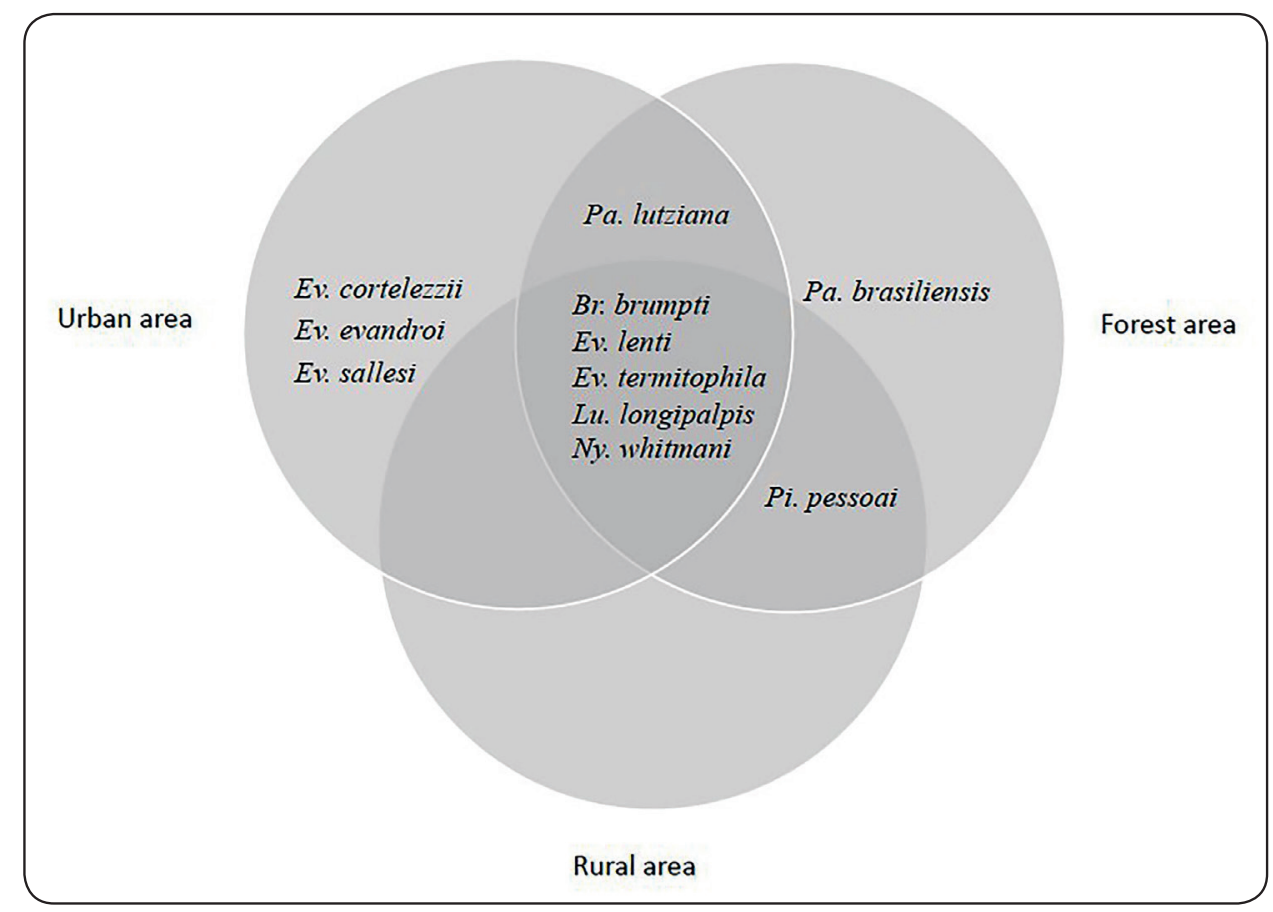

FIGURE 3: Distribution of phlebotomine sand fly species in forest, rural, and urban areas. Itaúna, Minas Gerais, Brazil. June 2017 to May 2018 
Some sand fly species may be in the early stages of adaptation to the urban environment and, although apparently rare and without epidemiological importance, they would be adaptable and able to perform vector functions ${ }^{44}$. Despite previous studies on sand fly biology and behavior, some gaps related to the synanthropy of these insects remain to be clarified.

Our results emphasize the importance of studying the ecology/biology and behavior of phlebotomine sand flies, demonstrating their epidemiological role in the transmission of leishmaniases in urban centers. Thus, the potential of some species of phlebotomine sand flies as vectors of Leishmania, along with their habits and synanthropy, should be considered by the competent health agencies.

\section{ACKNOWLEDGMENTS}

We wish to thank the inhabitants of Itaúna for allowing access to their homes and the Municipal Health Department for their logistical support.

\section{AUTHORS' CONTRIBUTIONS}

NCLP, EMM, AJVP, JVL and DMP participated in the collection of phlebotomines; FOLS, ESD and RSL were responsible for specimen identification; FOLS, ESD, EMM and NCLP participated in taxonomic discussions; CLFD was responsible for the statistical analysis of the results; NCLP, EMM, ESD and CLFD prepared the manuscript. All authors have read and approved the final version of the article.

\section{CONFLICT OF INTEREST}

The authors declare that there is no conflict of interest.

\section{REFERENCES}

1. World Health Organization (WHO). Report of the Consultative Meeting on Cutaneous Leishmaniasis. Leishmaniasis Control Program. Geneva:WHO; 2007. 31 p.

2. Lainson R, Shaw JJ. The role of animals in the epidemiology of South American leishmaniasis. In: Lumsden WHR, Evans DA, editors. Biology of the Kinetoplastida. London: Academic Press; 1979. p. 1-116.

3. Ministério da Saúde (MS). Fundação Nacional de Saúde. Centro Nacional de Epidemiologia. Leishmaniose Visceral no Brasil: situação atual, principais aspectos epidemiológicos, clínicos e medidas de controle. Boletim Epidemiológico. 2001;6:1-11.

4. Grimaldi GJr, Tes RB. Leishmaniases of the New World: current concepts and implications for future research. Clin Microbiol Rev. 1993;6(3):230-50.

5. Marzochi MCA, Marzochi KBF. Tegumentary and visceral leishmanioses in Brazil emerging anthropozoonosis and possibilities for their control. Cad Saude Publica. 1994;10(Suppl 2):359-75.

6. Nuorteva P. Synanthropy of blowflies (Dipt., Calliphoridae) in Finland. Ann Entomol Fenn. 1963;29:1-49.

7. Cardenas R, Sandoval CM, Rodriguez-Morales AJ, Franco-Paredes C. Impact of climate variability in the occurrence of leishmaniasis in northeastern Colombia. Am J Trop Med Hyg. 2006;75(2):273-7.

8. Rebêlo JMM, Oliveira ST, Barros VLL, Silva FS. Flutuação sazonal dos flebotomíneos (Diptera, Psychodidae) em área de colonização recente do município de Buriticupu, Amazônia maranhense, Brasil. Rev Bras Entomol. 2001;45:11-6.
9. Brazilian Institute of Geography and Statistics (IBGE). 2018. Available from: https://cidades.ibge.gov.br/brasil/mg/itauna/panorama.

10. Pugedo H, Barata RA, França-Silva JC, Silva JC, Dias ES. HP: um modelo aprimorado de armadilha luminosa de sucção para a captura de pequenos insetos. Rev Soc Bras Med Trop. 2005;38:70-2.

11. Galati EAB. Morfologia e taxonomia: classificação de Phlebotominae. In: Rangel, EF, Lainson R, editors. Flebotomíneos do Brasil. Rio de Janeiro: Editora Fiocruz; 2003. p. 23-52.

12. Marcondes CB. A proposal of generic and subgeneric abbreviations of phlebotominessandflies (Diptera: Psychodidae: Phlebotominae) of the world. Entomol News. 2007;118:351-6.

13. National Institute of Meteorology (INMET). 2018. Banco de dados meteorológicos para ensino e pesquisa. Available from: http://www. inmet.gov. br/portal/index.php?r=bdmep/bdmep.

14. Lainson R, Shaw JJ, Braga RR, Ishikawa EA, Souza AA, Silveira FT. Isolation of Leishmania from monkeys in the Amazon Region of Brazil. Trans R Soc Trop Med Hyg. 1988;82(2):231.

15. Chaves LF, Pascual M. Climate cycles and forecasts of cutaneous leishmaniasis, a nonstationary vector-borne disease. PLoS Med. 2006;3(8):e295.

16. Dantas-Torres F, Solano-Gallego L, Baneth G, Ribeiro VM, de Paiva-Cavalcanti M, Otranto D. Canine leishmaniosis in the Old and New Worlds: unveiled similarities and differences. Trends Parasitol. 2012;28(12):531-8.

17. Desjeux P. Leishmaniasis: current situation and new perspectives. Comp Immunol Microbiol Infect Dis. 2004;27(5):305-18.

18. Dantas-Torres F, Brandão-Filho SP. Visceral leishmaniasis in Brazil: revisiting paradigms of epidemiology and control. Rev Inst Med Trop Sao Paulo. 2006;48(3):151-6.

19. Ministério da Saúde (MS). Sistema de Informações de Agravos de Notificação. SINAN. Leishmaniose Visceral. Notificações registradas: banco de dados. Available from: http://www.saude.gov.br/saude-de-a-z/ leishmaniose-visceral.

20. Shaw J, Rosa AT, Souza A, Cruz AC. Transmissão de outros agentes: os flebotomíneos brasileiros como hospedeiros e vetores de determinadas espécies. In: Rangel EF, Lainson, R, editors. Flebotomíneos do Brasil. Rio de Janeiro: Editora Fiocruz; 2003. p. 337- 51.

21. Lopes JV, Michalsky EM, Pereira NCL, De Paula AJV, Lara-Silva FO, Fortes Dias CL, et al. Entomological Studies in Itaúna, Brazil, an area with visceral leishmaniasis transmission: fauna survey, natural leishmania infection, and molecular characterization of the species circulating in phlebotomine sand flies (Diptera: Psychodidae). J Med Entomol. 2019;56(5):1368-76.

22. Saraiva L, Lopes JDS, Oliveira GBM, Batista FDA, Falcão AL, Andrade Filho JD. Estudo dos flebotomíneos (Diptera: Psychodidae) em área de leishmaniose tegumentar americana nos municípios de Alto Caparaó e Caparaó, Estado de Minas Gerais. Rev Soc Bras Med Trop. 2006;39(1):56-63.

23. Barata RA, Silva JC, Costa RT, Fortes-Dias CL, Silva JC, Paula EV, et al. Phlebotomine sand flies in Porteirinha, an area of American visceral leishmaniasis transmission in the State of Minas Gerais, Brazil. Mem Inst Oswaldo Cruz. 2004;99(5):481-7.

24. Resende MC, Camargo MCV, Vieira JRM, Nobi RCA, Porto MN, Oliveira CL, et al. Seasonal variation of Lutzomyia longipalpis in Belo Horizonte, State of Minas Gerais. Rev Soc Bras Med Trop. 2006;39(1):51-5.

25. Dias ES, França-Silva JC, da Silva JC, Monteiro EM, de Paula KK, Gonçalves CM, et al. Sandflies (Diptera: Psychodidae) in an outbreak of cutaneous leishmaniasis in the State of Minas Gerais. Rev Soc Bras Med Trop. 2007;40(1):49-52. 
26. Ximenes MFFM, Castellón EG, Souza MDEF, Menezes AA, Queiroz $\mathrm{J}$, Macedo VP, et al. Effect of abiotic factors on seasonal population dynamics of Lutzomyia longipalpis (Diptera: Psychodidae) in Northeastern Brazil. J Med Entomol. 2006;43(5):990-5.

27. Michalsky EM, Fortes-Dias CL, França-Silva JC, Rocha MF, Barata RA, Dias ES. Association of Lutzomyia longipalpis (Diptera: Psychodidae) population density with climate variables in Montes Claros, an area of American visceral leishmaniasis transmission in the state of Minas Gerais, Brazil. Mem Inst Oswaldo Cruz. 2009:104(8):1191-3.

28. Almeida PS, Minzão ER, Minzão LD, Silva SR, Ferreira AD, Fachada O. Aspectos ecológicos de flebotomíneos (Diptera: Psychodidae) em área urbana do município de Ponta Porã, Estado de Mato Grosso do Sul. Rev Soc Bras Med Trop; 2010;43(6):723-7.

29. Lana RS, Michalsky EM, Lopes LO, Lara-Silva FO, Nascimento JL, Pinheiro LC, et al. Ecoepidemiological aspects of visceral leishmaniasis in an endemic area in the Steel Valley in Brazil: An ecological approach with spatial analysis. PLoS One. 2018;13(10):e0206452.

30. Ricklefs RE. A economia da natureza. Rio de Janeiro: Editora Guanabara Koogan; 2003. 503 p.

31. Pessoa FAC, Medeiros JF, Barret TV. Effects of timber harvest on phlebotomine sand flies (Diptera: Psychodidae) in a production forest: abundance of species on tree trunks and prevalence of trypanosomatids. Mem Inst Oswaldo Cruz. 2007;102(5):593-9.

32. Rosário IN, Andrade AJ, Ligeiro R, Ishak R, Silva IM. Evaluating the adaptation process of sand fly fauna to anthropized environments in a leishmaniasis transmission area in the Brazilian Amazon. J Med Entomol. 2017;54(2):450-9.

33. Teodoro U, Thomaz-Soccol V, Kühl JB, Santos DR, Santos ES, Santos AR, et al. Reorganization and cleanness of peridomiciliar area to control sand flies (Diptera, Psychodidae, Phlebotominae) in South Brazil. Braz Arch Biol Technol. 2004;47(2):205-12.

34. Thies SF, Bronzoni RVM, Michalsky EM, Santos ESD, Silva DJFD, Dias ES, et al. Aspects on the ecology of phlebotomine sand flies and natural infection by Leishmania hertigi in the Southeastern Amazon Basin of Brazil. Acta Trop. 2018;177:37-43.

35. Oliveira AG, Galati EAB, Oliveira O, Oliveira GR, Espíndola IAC, Dorval MEC, et al. Abundance of Lutzomyia longipalpis (Diptera: Psychodidae: Phlebotominae) and urban transmission of visceral leishmaniasis in Campo Grande, state of Mato Grosso do Sul, Brazil. Mem Inst Oswaldo Cruz. 2006;101(8):869-74.

36. Alvar J, Vélez ID, Bern C, Herrero M, Desjeux P, Cano J. WHO. Leishmaniasis control team. Leishmaniasis worldwide and global estimates of its incidence. PloS. 2012;1(7):e35671.

37. Rebêlo JM, Leonardo FS, Costa JM, Pereira YN, Silva FS. Sandflies (Diptera, Psychodidae) from an endemic leishmaniasis area in the cerrado region of the State of Maranhão, Brazil. Cad Saude Publica. 1999;15(3):623-30.

38. Ximenes MFFM, Souza MF, Castellón EG. Density of sand flies (Diptera: Psychodidae) in domestic and wild animal shelters in an area of visceral leishmaniasis in the state of Rio Grande do Norte, Brazil. Mem Inst Oswaldo Cruz. 1999;94(4):427-32.

39. Oliveira AG, Andrade Filho JD, Falcão AL, Brazil RP. Estudos de flebotomíneos (Diptera, Psychodidae, Phlebotominae) na zona urbana de cidade de Campo Grande, Mato Grosso do Sul, 1999- 2000. Cad Saude Publica. 2003;19(4):933-44.

40. Barata RA, França-Silva JC, Mayrink W, Silva JC, Prata A, Lorosa ES. Aspectos da ecologia e do comportamento de flebotomíneos em área endêmica de leishmaniose visceral, Minas Gerais. Rev Soc Bras Med Trop. 2005;38(5):421-5.

41. Maingon RD, Ward RD, Hamilton JG, Noyes HA, Souza N, Kemp SJ, et al. Genetic identification of two sibling species of Lutzomyia longipalpis (Diptera: Psychodidae) that produce distinct male sex pheromones in Sobral, Ceará State, Brazil. Mol Ecol. 2003;12(7):1879-94.

42. Melo F, Amaral M, Oliveira P, Lima W, Andrade M, Michalick M, et al. Diffuse intralobular liver fibrosis in dogs naturally infected with Leishmania (Leishmania) chagasi. Am J Trop Med Hyg. 2008;79(2):198204.

43. Michalsky EM, Guedes KS, Lara-Silva FO, França-Silva JC, Dias CL, Barata RA, et al. Natural infection with Leishmania infantum chagasi in Lutzomyia (Lutzomyia) longipalpis (Diptera: Psychodidae) sandflies captured in the municipality of Janaúba, State of Minas Gerais, Brazil. Rev Soc Bras Med Trop. 2011;44(1):58-62.

44. Martin MCB, Rebêlo JMM. Dinâmica espaço temporal de flebotomíneos (Diptera, Psychodidae) do município de Santa Quitéria, área de cerrado do Estado do Maranhão, Brasil. Iheringia Ser Zool. 2006;96(3):273-384. 